\title{
DEVELOPMENT AND PERFORMANCE EVALUATION OF COWPEA DEHULLER
}

\author{
Olajide O.G, Fawohunre A.J. and Alagha S.A. \\ Agricultural and Bio - Environmental Engineering Technology Department \\ Rufus Giwa Polytechnic, Owo
}

P.M.B. 1019

Owo, Ondo State, Nigeria

\begin{abstract}
A cowpea machine was developed using locally available materials to reduce drudgery attached to traditional dehulling of the seeds. The machine consisted of the dehulling chamber made from $1.5 \mathrm{~mm}$ thick galvanized metal sheet, the dehulling mechanism obtains its drive from a 3 phase $15 \mathrm{~kW}$ electric motor with a speed of $750 \mathrm{rpm}$. The principle of operation of the machine is by feeding the soaked cowpea through the hopper into the dehulling chamber which invariably brought about dehulling of the cowpea and the dehulled cowpea is collected through the outlet into the collector. The machine was evaluated based on soaking time and dehulling time. The results showed that the dehulling rate increases with increase in time of soaking. The optimum level of $98 \%$ efficiency was observed at 6 minutes and 15 minutes time of soaking and time of dehulling respectively.
\end{abstract}

Keywords: Design, Performance Evaluation, Cowpea, Soaking time, Dehulling Machine, Efficiency.

\section{INTRODUCTION}

The cowpea (vigna unguiculata) is an annual herbaceous legume from the genus vigna. Vigna unguiculata is a member of the vigna (peas and beans) genus. Unguiculata is Latin for "with a small claw", which reflects the small stakes on the flower petals [1]. Some well-known common names for cultivated cowpeas include black eye pea, southern pea, Yardlongbean, Catjangand Crowder pea. [2]. Cowpea like most common legumes, are consumed in different forms and used for the preparation of various diets in Nigeria. One very form of consumption of cowpea is a steamed milled cowpea after dehulling either manually or mechanically. A large number of cowpea species are cultivated worldwide as ornamentals (in gardens, as shade trees), used as living fences and firebreaks, as soil binders, green manure, fodder for livestock, forage for honey bees, food for humans, in agroforestry and reforestation (nitrogen fixation), as pulp for paper production, fuel woods, timber and as sources of chemical (e.g. dyes, tannins), oil (industrial, food, aromatherapy), and medicines [3 - 4]. Cowpea like most common legumes, are consumed in different forms and used for the preparation of various diets in Nigeria. One very form of consumption of cowpea is a steamed milled cowpea after dehulling either manually or mechanically. [5-6] defined dehullng as the removal of the seed coat (hull) which results in the separation of cotyledon. Dehulling not only improves the cooking quality and reduces the antinutritional factors, but also improves protein quality, palatability and digestibility of pulses [7]. While Dehulling may be necessary in some legumes for preparation of "moin-moin", it may not be important in some varieties of some legumes [8]. Dehulling is a process employed to get rid of the outer pericarp and taste (hull) of most cereal grains, grain legumes, nuts and oil seeds using mechanical means. For small processing of cowpea dehuling is usually achieved manually while mechanical dehulling will be more ideal for commercial or large scale production especially for legumes with hard to cook phenomenon which makes manual dehulling rigorous, cumbersome and time consuming [9]. According to [10], cowpeas are not only a good source of protein but they are also important source of fiber, and they are naturally low in fat and cholesterol.

In Nigeria, the dehulling of cowpea are processed by women at home, and at village level working independently or organized into a formal group. These women hence developed an empirical knowledge of the physical and chemical characteristics and 
the functional properties of cowpea. The traditional processing methods are laborious; harvesting, drying, threshing, cleaning, soaking, dehulling (with the used of mortar and pestle), size reduction and storage are typical of the processes used in traditional methods of processing cowpea. Also, the mechanized method of dehulling cowpea including harvesting, drying, threshing, cleaning, soaking, dehulling, size reduction, primary storage, and storage using improved machineries. Dehulled cowpea production level in Nigeria is low because of the limitation of the widely employed traditional method of dehulling. Therefore, there is need for the ever increasing future demand for dehulled cowpea. This paper presents the report of the development and evaluation of a cowpea dehulling machine using available local materialswith the aim of increasing dehulled cowpea production on small - scale basis.

\section{MATERIALS AND METHODS}

\subsection{Design Considerations}

The factors considered in the designing and fabrication of the cowpea dehulling machine include: availability of materials, durability, rigidity, construction technique and cost of the materials.

\subsection{Design Analysis}

\subsubsection{Design of the dehulling unit}

The capacity of dehulling unit was designed by making close fitness with the auger conveyor and to avoid over feeding the machine by using eqn. 1

$$
\mathrm{Vdc}=\pi \mathrm{r}^{2} 1
$$

Where; $\mathrm{Vdc}=$ volume of the dehulling cylinder $\mathrm{r}=$ radius of dehulling chamber, $1=$ length of dehulling chamber

$$
\mathrm{Vdc}=3.142 \times 0.061^{2} \times 0.6=0.007 \mathrm{~m}^{3}
$$

\section{Volume of roller in dehulling chamber (vr)}

The volume of roller in the dehulling chamber is given in eqn. 2

$$
\mathrm{Vr}=\pi \mathrm{rr}^{2} \mathrm{lr}
$$

Where; $\mathrm{rr}=$ radius of roller, $\mathrm{lr}=$ length of roller

$$
\mathrm{Vr}=3.142 \times 0.048^{2} \times 0.56=0.0041 \mathrm{~m}^{3}
$$

\section{Volume of cowpeas in dehulling chamber (Vc)}

The volume of cowpeas (vc) in the dehulling chamber is obtained by subtracting the volume of roller (vr) in the dehulling chamber from the volume of the dehulling chamber (vdc)

$$
\begin{aligned}
& V_{c}=v d c-v r \\
& V_{c}=0.007-0.0041=0.003 m^{3 s}
\end{aligned}
$$

\section{Weight of cowpeas in dehulling chamber}


Where; $\mathrm{m}=$ mass of cowpeas, $\mathrm{g}=$ acceleration due to gravity

Also,

$$
\mathrm{m}=\rho \dot{\rho} \mathrm{v}_{\mathrm{c}}
$$

Where; $\dot{\rho}=$ bulk density of cowpea $=721 \mathrm{~kg} / \mathrm{m}^{3}, \mathrm{v}_{\mathrm{c}}=$ volume of cowpea $\mathrm{m}^{3}$

$$
\begin{gathered}
\mathrm{m}=721 \times 0.003=2.2 \mathrm{~kg} \\
. \quad \mathrm{w}_{\mathrm{c}}=21.6 \mathrm{~kg}
\end{gathered}
$$

\subsubsection{Hopper Design}

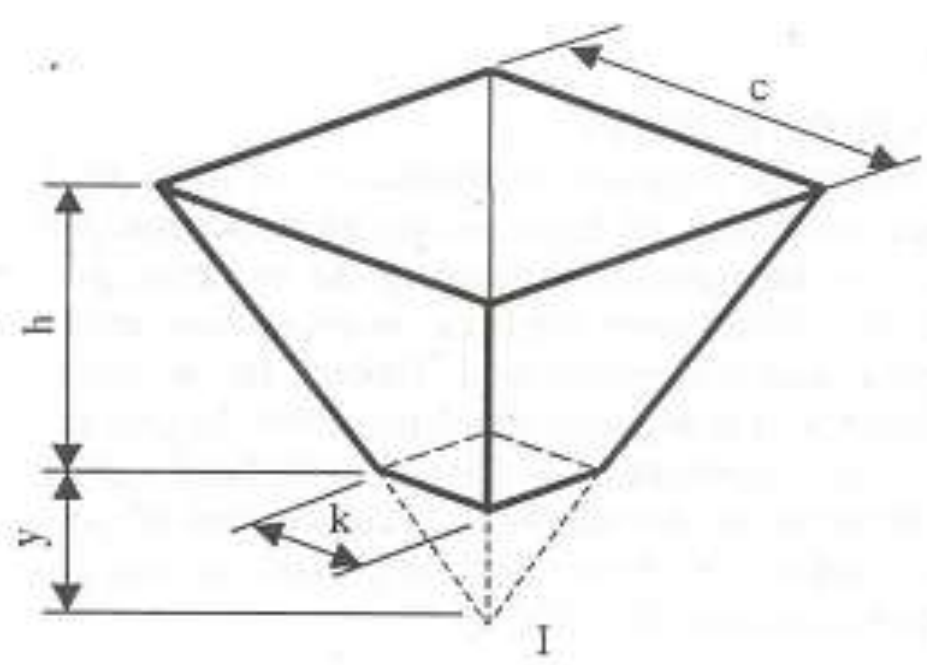

Fig.1: Hopper

Where,

$\mathrm{h}$ is the height of frustum $=144 \mathrm{~mm}, \mathrm{y}$ is the high of the small pyramid $=7.2 \mathrm{~mm}$,

$\mathrm{c}$ is the length of one side of the square base of the big pyramid $=200 \mathrm{~mm}, \mathrm{k}$ is the length of one side of the square base of the small pyramid $=86 \mathrm{~mm}$

The volume of frustum is calculated using the equation according given by [11] as:

Volume of frustum $={ }^{1 /}\left(\mathrm{c}^{2}(\mathrm{~h}+\mathrm{y})-\mathrm{k}^{2} \mathrm{y}\right)$

$$
\begin{aligned}
& ={ }^{1 /}{ }_{3}\left(0.20^{2}(0.144+0.72)-0.086^{2} \times 0.72\right) \\
& ={ }^{1 /}{ }_{3}(0.04(0.864)-(0.005325)
\end{aligned}
$$




$$
=0.029 \mathrm{~m}^{3}
$$

\subsubsection{Shaft Design}

This is calculated using the equation according to [12]

$\mathrm{d}^{3}=\frac{16 n}{\pi S s} \sqrt{(K b \times C B M)^{2}+(K t \times C T M)^{2}}$

Where,

$\mathrm{d}$ is the diameter of the shaft in $\mathrm{mm}$, Ss is the allowable shear stress of metal $=55 \times 10^{6} \mathrm{~N} / \mathrm{m}^{2}$, CBM is bending moment, CTM is the torsional moment $=3.2 \mathrm{~N} / \mathrm{m}, \mathrm{n}$ is factor of safety $=2, \mathrm{~kb}=2.0 \& \mathrm{kt}=1.5$ are combine shock and fatigue factor applied to bending and torsional moments respectively

$\mathrm{d}$ was computed as $30 \mathrm{~mm}$. Thus, a shaft of $32 \mathrm{~mm}$ was selected

\section{RESULTS AND DISCUSSION}

\subsection{Dehulling efficiency}

Figure 2 Shows the relationship between the efficiency and the time of soaking, it was observed that at 6 minutes of soaking the dehulling rate was at optimum level of $98 \%$ efficiency. This shows that this is the best period of soaking for dehulling of cowpea.

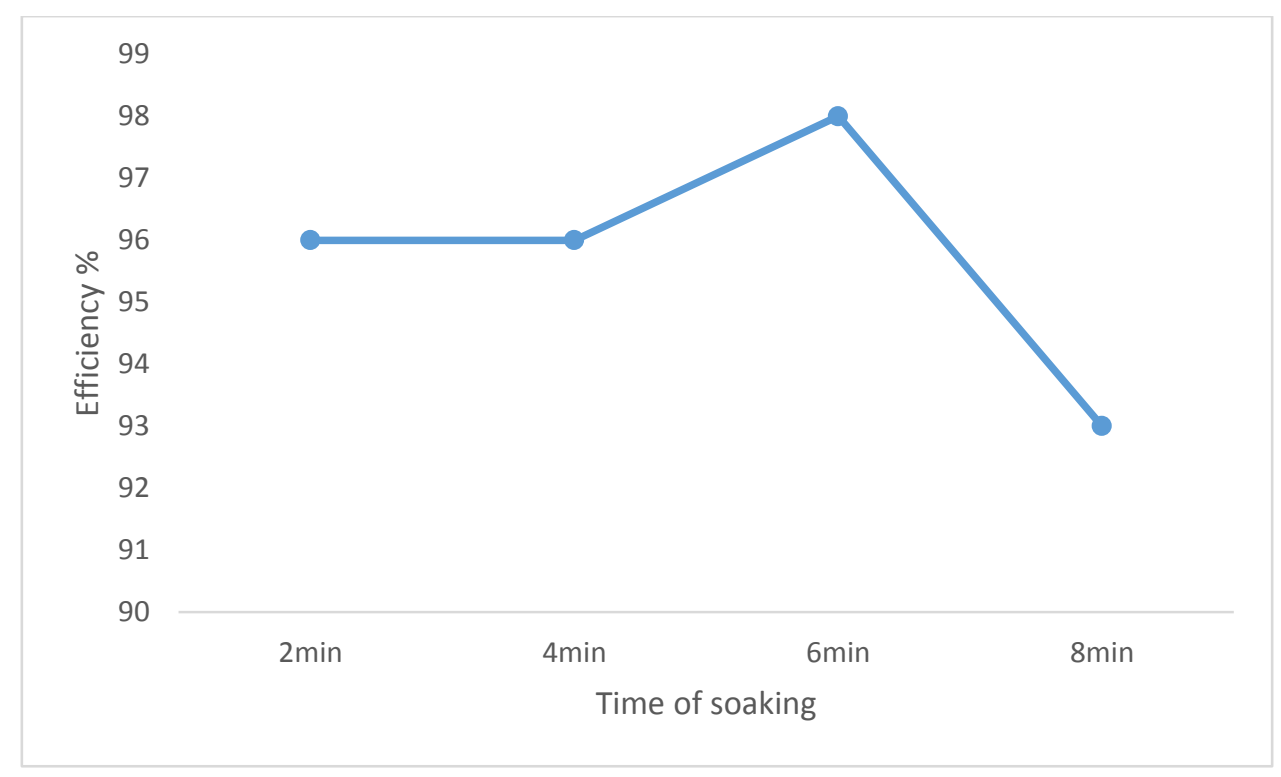

Fig. 2: Efficiency against Soaking time 
Figure 3 Shows that the machine performs optimally after running period of 15 minutes with $98 \%$ efficiency, after increasing the running period to 20 minutes it was discovered that the efficiency dropped to $93 \%$ which means longer period of running might cause the cowpeas to break, thus reducing the dehulling efficiency.

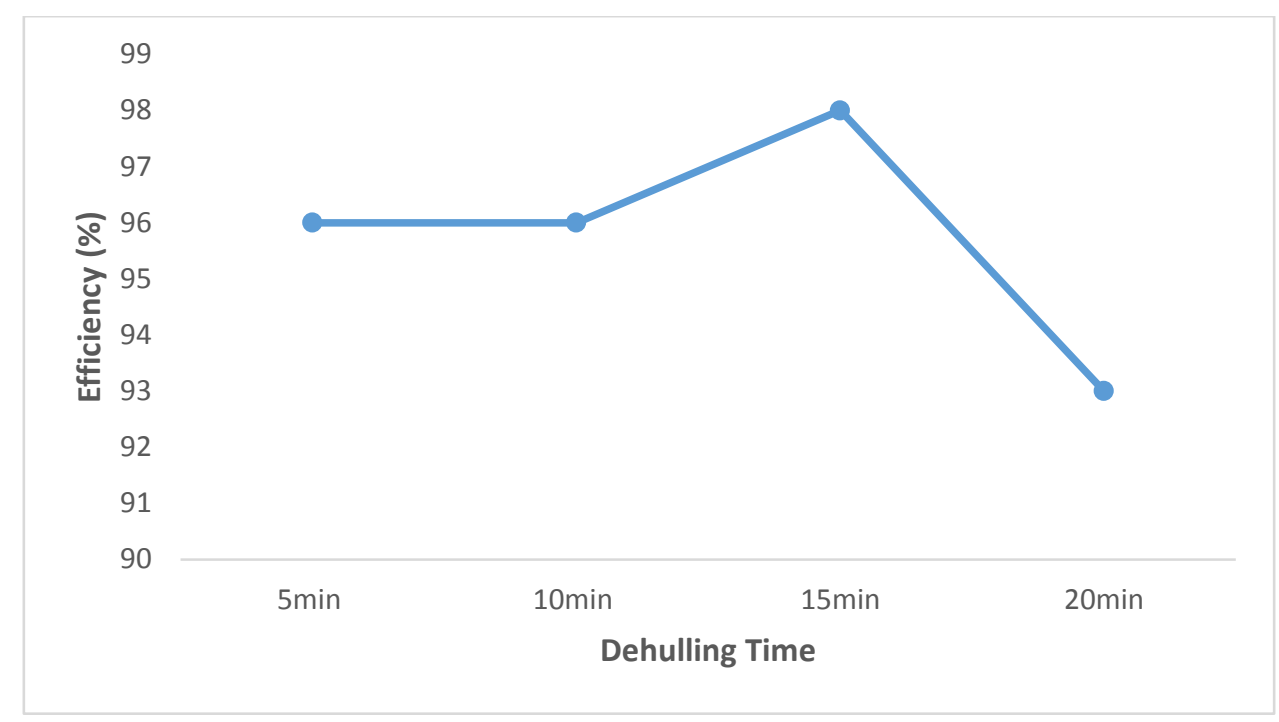

Fig. 3: Dehulling efficiency against Dehulling Time

\subsection{CONCLUSION AND RECOMMENDATION}

\subsection{Conclusion}

A Cowpea dehulling machine with an auger and rubber roller cylinder was designed, fabricated, tested and had satisfactory performance. The optimum efficiency of $98 \%$ was observed at 6 minutes and 15 minutes of soaking and dehulling time respectively. Maximum soaking time of 6 mins was appropriate for minimal percentage of broken seeds of the machine under study.

\subsection{Recommendation}

From the study, stainless steel should be used for fabrication of the shaft and dehulling chamber. The adopted dehulling tools design system can be optimized to improve the machine to dehull different types of legumes and its performance evaluation should also carried out. The machine is recommended for small and medium scale farmers to dehull cowpea on wet basis.

\section{REFERENCES}

[1] Small and Ernest (2009). Top 100 food plants. NRC Research press.p.104.ISBN 978-0-660-19858-3

[2] Timko, M.P; Ehlers, J.D; Roberts, P.A (2007). "Cowpea” in Kole, C. Pulses, sugar and Tubercrops, Genome -mapping and molecular Breeding in plants 3.Berlin, Heidelberg:Springer Verlag. PP.49-67 
International Journal of Advances in Scientific Research and Engineering (ijasre), Vol 5 (8), August-2019

[3] Duke, J.A, 1992 Handbook of legumes of economic importance. Plenom Press, New York, USA

[4] Graham, P, H, and C.P Vance 2003. Legumes: Importance and constrains to greater use. Plant physiology 137:872-877

[5] Ogunnigbo C.O., Adetan D.A. and Olusunmade O.F (2018): Assesment of a modified mixer for wet dehilling of cowpea (Vigna unguiculata). Agricultural Engineering International: CIGR Journal, 20(2): 239 -247

[6] Babatunde, O.O. (1995): Development and performance evaluation of a manually cowpea dehulling, machine for soaked cowpea. Journal of Agricultural Engineering and Technology. 3(1): 1 - 7

[7] Salunke, D.K. Jadhar, S.J. nadChavan, J.K, (1986)“Chemical, Biochemical and biological signifaceance of polyphenols in cercels and legumes, "Critical Reviews in food science and Nutrition, Vol.17, No.31986, pp.277395.

[8] Akinjayeju, O. and Enude O.T. (2002) Effects of Dehulling on some properties of cowpea (VignaUnguiculataWalp. L.) Flours, “Italian Journal of Food Science, Vol. 14, No.1, 2002, pp. 53-58

[9] Akinjayeju, O. and Bisisriyu S. (2004) "comparative studies of come properties of undehulled, mechanically dehulled and Manually Dehulled cowpea (VignaUnguiculataWalp. L) Flours, "International Journal of food science and Technology, Vol.39,No.4,2004,pp.355-360.doii/j.1365-2621.2004.00792-X

[10] Skerman, P.J., Cameroon, D.G and Riverus, F. (1998). Tropical Forage. $2^{\text {nd }}$ Ediion, FAO. Italy.

[11] Adejuyigbe, S.B. and Bolaji B.O. (2005): Design, fabrication and performance evaluation of beans dehuller. Journal of science and technology. Vol 25(1), pp 125 - 132

[12] Khumi, R.S and Gupta J.K. (2004): Machine design: shaft, v - belt and rope drive. S Chand and co. ltd New Delhi. Pp $465-498,657-659$ 